\title{
Significance of Adaptation Indicators Among Highly-Qualified Athletes in Terms of Transmeridian Trips Influence Taking into Account Gender and Specialization
}

\author{
Abramova T.F. \\ Federal Scientific Center All-Russian Scientific Research \\ Institute of Physical Culture \\ Moscow, Russia \\ atf52@bk.ru
}

\author{
Nikitina T.M. \\ Federal Scientific Center All-Russian Scientific Research \\ Institute of Physical Culture \\ Moscow, Russia \\ tanya_nikitin@mail.ru
}

\author{
Yashina E.R. \\ V.D. Shashin public company "Tatneft" \\ Almetyevsk, Russia \\ socinstitut@mail.ru
}

\begin{abstract}
The article considers the significance of temporary adaptation markers among highly-qualified racing skiers at the final stage of a yearly cycle of training during the flight to the east. On the basis of correlational analysis of dynamic indices rows of morphological state, cardiovascular and vegetative nervous system functional state, biochemical markers of adaptation, received in everyday monitoring among 16 highly-qualified racing skiers (men, women, age -26,5 $\pm 3,1$ years old, sports experience- $16,9 \pm 3,7$ years). They specialize in disciplines with different methodical orientation (distance and sprint). We revealed informative indices of temporary adaptation, differentially significant for temporary adaptation irrespective of gender and specialization, for adaptation taking into account gender characteristics and strict methodical orientation of the training process.
\end{abstract}

Keywords-temporary adaptation; racing skiers; men; women; distance training; sprint training; final stage of training.

\section{INTRODUCTION}

Organism adaptation of highly-qualified athletes to tense muscular activity in terms of the main starts of the season becomes more complicated because of several factors, including individual characteristics of an athlete. They include the level of physical readiness, acclimatization experience and competitive practice experience, the main start of the season location, its chronobiological and climatic-geographical characteristics in terms of considerable differences from the place of living.

Transmeridian trip leads to disbalance of inner and outer daily rhythms of a new zone time with resulting functional abilities deterioration because of inner rhythms transformation heterochrony in vital systems during the period of desynchronosis. It is reflected in central nervous system, hormonal, vegetative nervous and cardiovascular system functioning and causes adaptation mechanisms tension [1] - [11].

The problem of athlete's adaptation processes optimization as the base for the best performance in every case of training for the main start of a season in terms of chrono-zone factor influence is provided with the significant markers of adaptation determination with further their changeability revelation at the stages of extreme desynchronosis and after overcoming it in terms of precompetitive training and competitions, taking into account the results of performance. This forms the base of training planning optimization taking into account methodical orientation and individualization of training.

Significant markers of adaptation revelation, as a rule, is realized on the basis of functional state indices changeability, which provide physical working capacity being oriented toward phase character of desynchronosis reduction processes [1]-[3]. This reflects composite influence of different factors- age, gender, specific specialization in a kind of sport, disguising the influence of chrono-zone effect itself.

The aim of the research work is to specify the importance of adaptation indicators of highly-qualified athletes' functional state in terms of transmeridian trip influence, taking into account gender and specialization. 


\section{METHODS}

The research was held by the example of training highly-qualified skiers for the stage of World Cup. It was organized in terms of XXIII Olympic Games-2018 (Republic of Korea, mountain-skiing complex Alpenziya - low-hill terrain; air temperature-within the range $-9,3$ till $0,2^{\circ} \mathrm{C}$, humidity- $67 \%$ ), which underlined the main influence of desynchronosis factor (6 hour shift in time) on adaptation processes.

Three groups of racing skiers took part in the research. They had direct 8-hours flight Moscow- Seoul and arrived in Pyeongchang (Republic of Korea) 9 days before the beginning of the competitions. The groups included athletes of different gender and methodical orientation of training: men, the group of distance training; men, the group of sprint training; women, the group of distance training; in general 16 people, which is presented in table I.

The methods of general indicators estimation during adaptive processes in everyday monitoring are the following: the indices determination of psychological state (subjective health state, appetite and the desire to train estimation), morphological state (height and body weight, muscular and fat mass using calipermetry), cardiovascular and vegetative nervous system (blood pressure - systolic blood pressure (SBP) and diastolic blood pressure (DBP), pulse blood pressure- PBP, HR ( rate) at rest and orthostatic test using tonometry, puslometry and electrocardiography (ECG)), biochemical indices of blood (oxygen-transporting system, protein, and mineral metabolism, fermentative activity). Athletes were examined in the morning, every day during 12 days of pre-competitive (9 days) and competitive (3days) training.

TABLE I. AGE-RELATED AND QUALIFICATION CHARACTERISTIC OF RACING SKIERS GROUPS

\begin{tabular}{|c|c|c|c|c|c|c|}
\hline \multirow{2}{*}{ Group } & people & years & Age & Experience & \multicolumn{3}{|c|}{ Qualification/ title } \\
\cline { 2 - 7 } & & $\begin{array}{c}\mathrm{ms} \\
\text { (master } \\
\text { of } \\
\text { sport) }\end{array}$ & $\begin{array}{c}\text { wca } \\
\text { (World- } \\
\text { class } \\
\text { athlete) }\end{array}$ & $\begin{array}{c}\text { Mms } \\
\text { (Merited } \\
\text { Master } \\
\text { of } \\
\text { Sports })\end{array}$ \\
\cline { 2 - 7 } & $\mathrm{X} \pm \sigma$ & $\mathrm{X} \pm \sigma$ & $\%$ & $\%$ & $\%$ \\
\hline $\begin{array}{c}\text { Men - } \\
\text { distance }\end{array}$ & 8 & $\begin{array}{c}26,8 \\
\pm 3,3\end{array}$ & $17,0 \pm 3,3$ & 62,5 & 37,5 & - \\
\hline Men - sprint & 2 & $\begin{array}{c}25,0 \\
\pm 4,2\end{array}$ & $15,5 \pm 6,4$ & 50,0 & - & 50,0 \\
\hline $\begin{array}{c}\text { Women - } \\
\text { distance }\end{array}$ & 6 & $\begin{array}{c}25,3 \\
\pm 2,4\end{array}$ & $14,5 \pm 1,7$ & 100,0 & - & - \\
\hline Total & 16 & $\begin{array}{c}26,5 \\
\pm 3,1\end{array}$ & $16,9 \pm 3,7$ & 63,2 & 26,3 & 10,5 \\
\hline
\end{tabular}

\section{RESULTS}

According to the observation results we made several conclusions, based on phase character of physical readiness indices dynamics and functional state of athletes of different specialization and gender in groups. We revealed the leading functional indices of adaptation to the training loads, combined with time factor influence: regulation mechanisms of vegetative-vascular system (PBP, BP and $\mathrm{HR}$ in orthostasis); the main hormones dynamics, which determine the balance of metabolism (cortisol and free testosterone, their ratio); the level of protein (general protein, urea) and carbohydrate (glucose and insulin) metabolism indices, the level of magnesium, aspartate aminotransferase activity (AAT); subjective estimation of sleep quality and the desire to train [7].

At the same time, for functional state indices we didn't define differentiation of gender, specific specialization and priority time factor influence on adaptation of highlyqualified athletes' organism.

For this purpose we realized correlation analysis of dynamic rows of indices. They consider morphological level, cardiovascular and vegetative system, biochemical markers of adaptation and psychological state, between the groups of athletes: men-sprint and men-distance; mendistance and women- distance; men-sprint and womendistance.

According to the results of correlation analysis 4 blocks of indices were defined. They are connected with the individual characteristics of the training loads bearing; gender; methodical orientation of training; the influence of chronozone factor, which is presented in table II.

TABLE II. INTERCONNECTION OF ORGANISM FUNCTIONAL STATE INDICES AMONG HIGHLY QUALIFIED RACING SKIERS DURING 12 DAYS OF PRE-COMPETITIVE AND COMPETITIVE TRAINING

\begin{tabular}{|l|c|c|c|}
\hline \multirow{2}{*}{ Indices } & \multirow{2}{*}{ Men } & \multicolumn{2}{|c|}{ Men - Women } \\
\cline { 2 - 4 } & $\begin{array}{c}\text { sprint } \\
\text { distance }\end{array}$ & $\begin{array}{c}\text { sprint - } \\
\text { distance }\end{array}$ & distance \\
\hline Hemoglobin & 0,66 & - & - \\
\hline Hemoglobin & 0,69 & - & - \\
\hline Glucose & 0,59 & - & 0,47 \\
\hline Calcium & - & - & 0,50 \\
\hline Phosphor & - & - & 0,64 \\
\hline Urea & 0,67 & - & - \\
\hline General protein & $\mathbf{0 , 5 1}$ & $\mathbf{0 , 6 0}$ & $\mathbf{0 , 8 5}$ \\
\hline Cortisol & $\mathbf{0 , 9 1}$ & $\mathbf{0 , 8 4}$ & $\mathbf{0 , 7 3}$ \\
\hline General testosterone & 0,56 & - & - \\
\hline Free testosterone & $\mathbf{0 , 8 8}$ & $\mathbf{- 0 , 7 7}$ & $\mathbf{- 0 , 7 5}$ \\
\hline $\begin{array}{l}\text { DHT } \\
\text { dihydrotestosterone }\end{array}$ & $\mathbf{0 , 5 4}$ & $\mathbf{0 , 5 3}$ & $\mathbf{0 , 6 3}$ \\
\hline SBP standing & $\mathbf{0 , 6 1}$ & $\mathbf{0 , 4 8}$ & $\mathbf{0 , 5 7}$ \\
\hline HR lying & 0,60 & - & - \\
\hline HR sitting & 0,80 & - & - \\
\hline HR standing & 0,55 & - & - \\
\hline Muscle mass, kg & 0,84 & - & - \\
\hline Muscle mass, $\%$ & 0,86 & - & - \\
\hline Fat mass, kg & 0,67 & - & - \\
\hline Fat mass, $\%$ & 0,72 & - & - \\
\hline
\end{tabular}

The indices, which are mainly connected with individual readiness for the load bearing, include the indices not connected according to variability in terms of the interested time: psychological state, body weight, BP (blood pressure) and PBP at rest and orthostatic test; biochemical 
[5] Lents N.A., Razumovskiy E.A. Temporary adaptation, weather and qualified athletes' working capacity. Olympic Games in Atlanta: weather, acclimatization and athletes' working capacity. Moscow: OKR. 1995, pp. 10-17.

[6] Meerson F.Z., Pshennikova M.G. Adaptation to stress situations and physical loads. Moscow: Medicine. 1988, 256.

[7] Yashina E.R., Grushin A.A. Peculiarities of chronobiological and climatic-geographical adaptation of highly-qualified athletes, taking into account characteristics of kinds of sport. Scientific monograph. FSBE FSC ASRIPC. Moscow: Griffon. 2017, 708.

[8] Platonov V.N. System of training athletes in the Olympic sport. Moscow: Soviet sport. 2005, 820.

[9] Eckel-Mahan K., Sassone-Corsi P. Metabolism and the Circadian Clock Converge. Physiol Rev. 2013, 93(1), pp. 107-135.

[10]Klein K.E., Hermann R., Kuklinski P., Wegmann Y.M. Circadian performance rhythms: Experimental studies in air operations. Vigilance: theory, Operational Performance and Physiological Correlates. New York:Plenum publ.Corp. 1977, pp. 111-132.

[11]Nicholson A.N., Pascoe P.A., Spenser M.B., Benson A.J. Jet lag and motion sickness. British Medical Bulletin. 1993, vol.49, 2, pp. 285304.

[12]Alexsandr S. Kuznetsov, Zinaida M. Kuznetsova. Integrated application of rehabilitation means in circannian training cycle of highly-qualified greco-roman style wresltlers. Pedagogicopsychological and medico-biological problems of physical culture and sport. 2017, vol. 12(4), pp. 6-14. DOI: 10/14526/04_2017_259.

There are indices, which are directly connected with all groups, irrespective of gender and specific specialization, which can be explained as markers of own chronozone adaptation: cortisol, general protein concentration in blood, lesser - dihydrotestosterone concentration, systolic blood pressure in standing position.

Moreover, there is interconnection between all groups of athletes according to the level of free testosterone, positive one- between the groups of men, negative onebetween the group of women and two groups of men of different methodical orientation of training.

\section{CONCLUSION}

Summarizing, we may conclude that adaptation to tense muscular activity in terms of chronic biological factor functioning is conditioned by the whole spectrum of influences, including gender identity, the specificity of the kind of sport, individual peculiarities of physical readiness on the basis of priority influence of hormonal shifts. They are reflected in the main metabolism hormones changes cortisol and testosterone. This should be taken into account during means and methods of control planning over training athletes not only for the main starts of the season, but also for any competitions in terms of considerable time shift.

\section{References}

[1] Dobrovolskaya N.A., Vlasov V.G. , Kuvshinchikov I.N., Shinshina S.I. Some peculiarities of temporary adaptation of athletes in terms of transmeridian flights. Pedagogics, psychology and medical-biological problems of physical upbringing and sport. 2009, 5, pp. 77-80.

[2] Ezhov S.N., Krivoshchekov S.G. Chronoresistance, biorhythms and functional reserves of an organism in desynchronosis phases during temporary adaptation. Bulletin of Siberian branch of the Russian Academy of Medical Sciences. 2004, 4, pp. 77.

[3] Iordanskaya F.A. Men and women in professional sport. The problems of gender dimorphism. Moscow: Soviet sport. 2012, 256.

[4] Kolesov A.I., Lents N.A., Razumovskiy E.A. Competitive activity and highly-qualified athletes training in different nature-geographic conditions - Moscow. 2003, pp. 293. 